Article

\title{
Chemistry and Microbiology of Urban Roof Runoff in Kraków, Poland with Ecological and Health Risk Implications
}

\author{
Magdalena Strzebońska, Agnieszka Gruszecka-Kosowska * (i) and Anna Kostka \\ Department of Environmental Protection, Faculty of Geology, Geophysics and Environmental Protection, \\ AGH University of Science and Technology, Al. Mickiewicza 30, 30-059 Kraków, Poland; \\ mstrzebo@agh.edu.pl (M.S.); kostka@agh.edu.pl (A.K.) \\ * Correspondence: agnieszka.gruszecka@agh.edu.pl
}

Received: 3 November 2020; Accepted: 27 November 2020; Published: 29 November 2020

\begin{abstract}
Urban rainwater samples, collected in various districts of Kraków during the period from the spring of 2019 to the winter of 2020, were investigated, and relevant risk implications were assessed. The contents of 31 components were determined, including: bacteria, fungi, $\mathrm{pH}$, $\mathrm{EC}, \mathrm{Cl}^{-}, \mathrm{N}-\mathrm{NO}_{3}, \mathrm{P}^{-\mathrm{PO}_{4}}, \mathrm{SO}_{4}{ }^{2-}, \mathrm{SiO}_{2}, \mathrm{~K}, \mathrm{Mg}, \mathrm{Ag}, \mathrm{Al}, \mathrm{Ba}, \mathrm{Ca}, \mathrm{Cu}, \mathrm{K}, \mathrm{Mg}, \mathrm{Mo}, \mathrm{Na}, \mathrm{Pb}, \mathrm{Sb}$, and $\mathrm{Zn}$. The highest contents of the investigated elements were determined in the industrial (eastern) part of Kraków. The values of toxicity potential were $<1$, indicating a lack of ecological risk. The value of contamination degree indicated moderate rainwater contamination in all analyzed elements $\left(C_{\text {deg }}=9.44\right)$. The total non-carcinogenic risk values, in both adults (hazard quotient $\left.(H Q)=1.38\right)$ and children $(\mathrm{HQ}=2.54)$, exceeded the acceptable level of one. Regarding individual elements in dermal contact, the acceptable level of $1 \times 10^{-6}$ was exceeded in $\mathrm{Pb}$ (adults carcinogenic risk $(\mathrm{CR})=4.87 \times 10^{-5}$, children $\mathrm{CR}=2.23 \times 10^{-5}$ ). The contents of the analyzed chemical compounds did not exceed the permissible levels adopted for drinking water; however, rainwater was significantly contaminated with respect to its microbiological parameters. Rainwater was suitable for non-potable use.
\end{abstract}

Keywords: rainwater; acid digestion; heavy metals; toxicity potential; contamination degree; health risk assessment; microbial risk assessment

\section{Introduction}

Climate changes and drought periods mean that alternative sources of water supplies are required. Rainwater harvesting (RWH) is an old practice [1], commonly used in arid and semi-arid regions [2,3]. In the countries that struggle with drought, rainwater is collected for potable purposes primarily. However, non-potable applications are practiced also, like washing, cleaning, toilet flushing, or plant watering $[4,5]$. Rainwater harvesting is still rarely practiced in urban regions of Poland [6], but as water resources in Poland are almost the lowest in Europe [7-9], RWH systems may become a necessity. Lately, roof runoff harvesting has also been promoted, as it can reduce excess runoff and consumption of potable water at the same time [10,11]. Although, roof runoff seems to be much cleaner than stormwater runoff $[12,13]$ it is not completely free form different types of contaminants, like heavy metals, organic pollutants, bacteria, and fungi [14-17]. The quality of harvested rainwater depends on roofing materials, climatic conditions, and atmospheric pollution [18]. According to Jędrzejczak [17], the urban runoff and the combined sewage overflows events occurring during wet weather are the major sources of water pollution. Moreover, the roof runoff may cause more than $80 \%$ of the load of heavy metals in the combined sewage system during wet weather [17].

There is no classification designed to determine rainwater pollution in terms of its potential use. Existing classifications for potable water are being used as they are the most strict according to 
water quality. Thus, in this study ecological and health risk assessment methods were also used to determine the reliable threats arising from pollutant contents in urban roof runoff for its potential non-potable usage.

Contamination of roof runoff might be an issue, especially in urban areas where the air quality is often poor due to road traffic effects and local pollution-emission sources [19-21]. As air humidity and wet deposition decrease the contents of pollutants in ambient air [19], they may further cause contamination of rainfall $[22,23]$. Air and precipitation pollutant concentrations may be augmented by various groups of contaminants that negatively affect human health. According to the European Environment Agency, the following are the most harmful air pollutants affecting human health in Europe: suspended in the air particulate matter $(\mathrm{PM})$, gaseous ozone $\left(\mathrm{O}_{3}\right)$ and nitrogen dioxide $\left(\mathrm{NO}_{2}\right)$, volatile liquid benzene $\left(\mathrm{C}_{6} \mathrm{H}_{6}\right)$, and bound with PM particles benzo[a]pyrene $(\mathrm{BaP})$ and heavy metals. The major sources of PM in the urban areas in Europe include fuel combustion during the heating season, household heating, and fuel combustion by road vehicles [24]. Long-term exposure to PM concentrations can shorten life expectancy [25]. Heavy metals, in particular: As, Cd, Co, Cr(VI), Ni, and $\mathrm{Pb}$ may cause the following health effects: cancer, cardiovascular diseases, or metabolic diseases, such as obesity and diabetes mellitus [26,27]. Organic pollutants, like BaP, bounded with PM particles, are primarily linked with carcinogenic effects in humans, but also show strong mutagenicity [25].

Airborne microorganisms like viruses (e.g., Influenza A and Measles/Rubeola, or Norwalk-like viruses, severe acute respiratory syndrome-associated coronaviruses, Sin Nombre viruses, Varicella-zoster viruses, or Variola viruses), bacteria (e.g., Bacillus anthracis, Francisella tularensis, Legionella pneumophila, Mycobacterium tuberculosis, or Yersinia pestis), and fungi (e.g., Aspergillus fumigatus, Aspergillus versicolor, Blastomyces dermatitidis, Chaetomium sp., Coccidioides immitis, Cryptococcus neoformans, Histoplasma capsulatum, Penicillium sp., Stachybotrys chartarum, and Trichoderma sp.) are also associated with potential adverse effects on human health [28,29]. Such types of bioaerosols are washed out from the air and roof surfaces, gutters and downpipes, causing roof runoff contamination. The presence of potentially pathogenic bacteria and other biological particles (e.g., microbiological toxins, viruses, fungi, protozoa, helminths, or feces) in rainwater has been reported by many authors (for a review, see [1,30,31]).

The health condition of city residents is inseparable from that of the urban environment. Air quality and urban rainwater quality are the main factors affecting the residents' health [32,33]. Thus, a risk assessment analysis has become an integral part of air pollution considerations and that points at the existence of adverse ecological and human-health effects [34,35]. Such an analysis became especially commonly applied in Poland [36-40], because 33 out of 50 most polluted cities in the European Union were found to be located in Poland [41]. In Kraków itself, research on risk implications due to air pollution has been conducted for a number of years [33,42-45].

As the research concerning roof water quality is limited, especially in Poland, the primary goal of our study was to determine the general condition of roof runoff water in Kraków. As there is a lack of clarity regarding standards and guidelines specifying rooftop runoff as the source of water, especially due to microbial contamination [13], in our investigation outlines for potable water were used in accordance to the conservative risk assessment principle determining the worst case scenario. Thus, taking the above into consideration, the objectives of the present research were the following: (1) to determine the contents of chemical and biological parameters in the roof runoff samples collected in Kraków in 2019-2020, (2) to determine the condition of roof runoff, based on permissible and recommended levels of contaminants defined by the US Environmental Protection Agency (US EPA), World Health Organization (WHO), and Polish legal acts and (3) to assess the potential ecological and health risk for the residents, arising from the composition of roof runoff. 


\section{Materials and Methods}

\subsection{Sampling Area}

The roof runoff samples were collected below vertical downpipes of roof gutters, since rainfall is usually harvested from roof infrastructure. To determine the general condition of roof-harvested rainwater, 31 parameters were analyzed, in the period from spring of 2019 to winter of 2020. The roof runoff samples were collected during precipitation events, in spring, autumn, and winter. Sampling sites were located in four specific districts of the City of Kraków: the Old Town (the southern part of District 1-KR1), the districts with high density of development and intensive traffic (the northern part of District 1-KR3 and Districts 2 and 3-KR4, KR5), and the industrial district (District 4-KR2) (Figure 1). Moreover, a reference site was established in the village of Mogilany (MOG), located about $20 \mathrm{~km}$ south of the center of Kraków, characterized by single-family households and low traffic intensity.

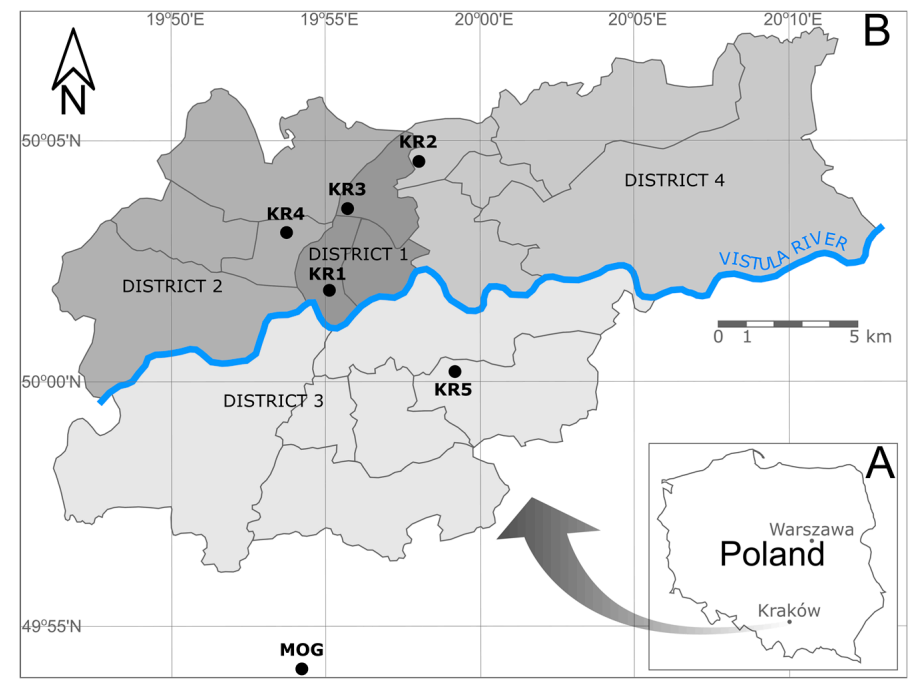

Figure 1. Sampling area: A-location of Kraków city at the map of Poland; B—sampling sites (KR1-KR5, Mogilany (MOG)) on the map of Kraków (four main districts in the city are marked with different shades of grey).

\subsection{Roof Runoff Sample Analysis}

The roof runoff samples collected from downpipes of roof gutters were collected into $250 \mathrm{~mL}$ vessels, for the purpose of cation (with acidification with $10 \mu \mathrm{L}$ of concentrated $\mathrm{HNO}_{3}$ ), anion (without acidification), and acid digestion analyses. Regarding microbial analysis, the samples of roof runoff were collected in sterile $250 \mathrm{~mL}$ glass bottles. The values of $\mathrm{pH}$ and conductivity were measured in situ in non-acidified roof runoff samples, using a Thermo Scientific Orion Star A329 Portable Multiparameter Meter, in accordance to the ISO 10523:2008 [46] and ISO 7888:1985 [47] protocols. The roof runoff samples were transported to the laboratory and immediately subjected to further procedures. Back in the laboratory, the samples were filtered by $0.45 \mu \mathrm{m}$ membrane filters and stored at $4{ }^{\circ} \mathrm{C}$ before further analysis. The concentrations of nitrate nitrogen $\left(\mathrm{N}-\mathrm{NO}_{3}\right)$ and phosphate phosphorus $\left(\mathrm{P}-\mathrm{PO}_{4}\right)$ were determined by the spectrometric method, using spectrophotometer UV Vis Camspec M501, based on the ISO 13395:1996 [48] and ISO 6878:2004 [49] protocols, respectively. The contents of chlorides were determined by titration-Mohr's method according to the ISO 9297:1989 protocol [50]. The acid digestion of the roof runoff samples was conducted in a closed vessel device, using temperature control and a microwave oven (Milestone ETHOS lab station), according to United States Environmental Protection Agency (US EPA) Method 3015A [51]. A total of $5 \mathrm{~mL}$ of $65 \% \mathrm{HNO}_{3}$ was added to $45 \mathrm{~mL}$ of each roof runoff sample, then samples were digested in a microwave oven, according to a 2-step program: 1st $\left(10 \mathrm{~min}\right.$, up to $\left.160^{\circ} \mathrm{C}\right)$ and 2 nd $\left(10 \mathrm{~min}\right.$, up to $\left.165^{\circ} \mathrm{C}\right)$, with 1000 Watts in each step. The concentrations 
of the analyzed cations, without and after acid digestion, were determined in the roof runoff samples, using an inductively coupled plasma-optical emission spectroscopy (ICP-OES) emission spectrometer, with inductive coupled plasma (Plasma 40 Perkin Elmer) and an ICP-MS mass spectrometer (ELAN 6100 Perkin Elmer), based on the ISO 11885:2007 [52] and ISO 17294-2:2016 [53] protocols, respectively.

Quantitative assessments of bacteria and fungi presence in roof runoff were conducted with the serial dilution method, complemented by the Petri dish streaking and spreading according to ISO 6222:1999 [54] and ISO 8199:2018 [55] protocols. The roof runoff samples were diluted ten-fold with physiological saline $\left(10^{-1}, 10^{-2}, 10^{-3}\right.$, and $\left.10^{-4}\right)$, then $0.1 \mathrm{~mL}$ of each dilution was transferred to nutrient agar plates (BTL, Poland) for bacteria and to wort agar plates (BTL, Poland) for fungi, and finally precisely spread on media surface, with a sterile spreader. All plates were incubated at room temperature $\left(22^{\circ} \mathrm{C}\right)$ until complete colonies were formed (if no new colonies were observed during the following three days, incubation was recognized to be completed). Then, the colonies observed at each plate were calculated, with regard to the recommendations of Tomasiewicz et al. [56] and the Bacteriological Analytical Manual of the United States Food and Drug Administration [57]. If confluent growth was observed, or the number of colonies did not fall within the range of 25-250, the data were not taken into account. Finally, the results obtained for particular samples were averaged and converted into colony-forming units (CFU) of either bacteria, or fungi, respectively, as existing in $1 \mathrm{~mL}$ of roof runoff. All parameters analyzed and the analytical methods applied are gathered in Table S1.

\subsection{Quality Control}

Water samples analyses were performed, maintaining the standard certified analytical quality control procedure according to the ISO 17294-1:2004 [58]. To achieve impartial and unequivocal ICP-MS results, the elements were also measured, using inductively coupled plasma-optical emission spectroscopy ICP-OES (OPTIMA 7300DV; Perkin Elmer, Waltham, MA, USA), according to US EPA 6020B [59] and ISO 11885:2007 [52] protocols. Reagent blanks and duplicates were used for quality assurance and quality control. All the reagents used in the laboratory analysis were analytically pure. The results of sample investigations were contained within the allowable error change values. Analytical bias was statistically insignificant $(p=0.05)$. The accuracy of ICP-MS and ICP-OES systems was satisfactory and verified by six different solution injections. Rh was used as an internal standard. In the ICP-MS analysis, element correction equations were applied to each element to minimize the impact of interferences. The measuring parameters for the ICP spectrometers used are given in Table S2. The limit of quantification (LOQ) values of the investigated elements were as follows (mg/L): $\mathrm{Cl}^{-}<0.7$, $\mathrm{N}-\mathrm{NO}_{3}<0.04, \mathrm{P}_{-} \mathrm{PO}_{4}<0.01, \mathrm{SO}_{4}{ }^{2-}<0.5, \mathrm{SiO}_{2}<0.2, \mathrm{Ag}<0.001, \mathrm{Al}<0.005, \mathrm{As}<0.001, \mathrm{~B}<0.01, \mathrm{Ba}<0.0005$, $\mathrm{Ca}<0.1, \mathrm{Co}<0.0002, \mathrm{Cr}<0.005, \mathrm{Cu}<0.001, \mathrm{Fe}<0.01, \mathrm{Hg}<0.0001, \mathrm{~K}<0.2, \mathrm{Li}<0.005, \mathrm{Mg}<0.1, \mathrm{Mn}<0.005$, $\mathrm{Mo}<0.0003, \mathrm{Na}<0.1, \mathrm{Ni}<0.001, \mathrm{~Pb}<0.0001, \mathrm{Sb}<0.0002$, $\mathrm{Se}<0.01$, and $\mathrm{Zn}<0.01$.

\subsection{Statistical Analysis}

Statistical analysis (mean, minimum, and maximum values) were determined, using a Microsoft Excel 2007 spreadsheet. The software package STATISTICA 13 (TIBCO Software Inc., Palo Alto, CA, USA) was used for further statistical analysis. Halves of the limit of detection (LOD) values were assigned to undetected results in statistical analysis, as recommended by the World Health Organization (WHO) [60].

\subsection{Risk Assessment}

Due to the fact that the investigated contaminants may pose a threat to the environment, the risk assessment approach was observed in this study. The risk assessment analysis was performed under three sections below. 


\subsubsection{Ecological Risk Assessment (ERA)}

To determine the potential ecological risks, arising from the presence of the investigated contaminants in roof runoff, the toxicity potential (TP) values were calculated, using Equation (1) [61]:

$$
\mathrm{TP}=\mathrm{C}_{\text {roof runoff }} / \mathrm{C}_{\text {recommended }}
$$

where: $\mathrm{C}_{\text {roof runoff }}$ is the concentration of a particular contaminant in roof runoff, collected in all sampling campaigns in 2019/2020 (mg/L), and $\mathrm{C}_{\text {recommended }}$ is the recommended limit for contaminant concentration, as the maximum contaminant level permissible in drinking water $(\mathrm{mg} / \mathrm{L})$, according to the US EPA Drinking Water Standards and Health Advisories [62]. Potential toxic deposition is stated for TP values $>1$ [61].

In addition, the contamination degree $\left(\mathrm{C}_{\mathrm{deg}}\right)$ and contamination factor $(\mathrm{CF})$ values were used to determine the pollution of roof runoff. That classification had been originally developed by Håkanson [63] for determining sediment contamination with heavy metals. Currently, this classification is being used for other elements and environmental compounds, including roof runoff contamination [61]. The contamination degree was calculated according to Equations (2) and (3) [61,63]:

$$
\begin{gathered}
\mathrm{C}_{\mathrm{deg}}=\sum_{\mathrm{i}=1}^{\mathrm{n}} \mathrm{CF}, \\
\mathrm{CF}=\mathrm{C}_{\mathrm{i}} / \mathrm{C}_{\mathrm{b}},
\end{gathered}
$$

where: $\mathrm{CF}$-contamination factor; $\mathrm{C}_{\mathrm{i}}$ - mean concentration of an individual element from all sampling campaigns in 2019/2020 (mg/L); and $C_{b}$ —background concentration, calculated according to Keresztesi et al. [61]. The classes of contamination, according to CF values, were as follows [63]: low contamination for $\mathrm{CF}<1$; moderate contamination for $1 \leq \mathrm{CF}<3$; considerable contamination for $3 \leq \mathrm{CF}<6$; and very high contamination for $\mathrm{CF} \geq 6$. The degrees of contamination, according to $C_{\text {deg }}$ values, were as follows [63]: low degree of contamination for $C_{\operatorname{deg}}<5$; moderate degree of contamination for $5 \leq C_{\text {deg }}<10$; considerable degree of contamination for $10 \leq C_{\operatorname{deg}}<20$; and very high degree of contamination for $C_{\text {deg }} \geq 20$.

\subsubsection{Human Health Risk Assessment (HHRA)}

To assess the human health risk arising from the contacts with roof runoff containing pollutants, the methodology developed by the United States Environmental Protection Agency (US EPA) was applied $[64,65]$. In the resident scenario, we analyzed ingestion and dermal contact with the investigated elements in roof runoff, in adults $(\geq 7)$ and children ( $0-6$ years). The inhalational pathway was not investigated due to the fact that the volatile compounds in roof runoff were not analyzed in the present study. The contents of contaminants were taken as the mean values of elements, determined after acid digestion; observing the conservative risk assessment principle, we wanted to achieve the highest risk values for the populations analyzed.

To estimate the daily intake of contaminants via the ingestion route, the average daily dose (ADD) values were calculated according to Equation (4) [66]:

$$
\mathrm{ADD}=(\mathrm{C} \times \mathrm{IR} \times \mathrm{EF} \times \mathrm{ED}) /(\mathrm{BW} \times \mathrm{AT}),
$$

To estimate the daily intake of pollutants via the dermal contact route, the dermal absorbed dose (DAD) values were calculated according to Equation (5) [66]:

$$
\mathrm{DAD}=(\mathrm{C} \times \mathrm{PC} \times \mathrm{SA} \times \mathrm{ET} \times \mathrm{EV} \times \mathrm{EF} \times \mathrm{ED}) /(\mathrm{BW} \times \mathrm{AT}),
$$

where: ADD—ingested average daily dose (mg/kg-day); DAD—dermal absorbed dose ( $\mathrm{mg} / \mathrm{kg}$-day); $\mathrm{C}-$ mean concentration of each element in the roof runoff samples after acid digestion $(\mathrm{mg} / \mathrm{L})$; 
IR—intake rate (L/day); PC—dermal permeability coefficient $(\mathrm{cm} / \mathrm{h})$; SA—skin surface area available for contact $\left(\mathrm{cm}^{2}\right)$; ET—event duration (h/event); EV—event frequency (events/day); EF—exposure frequency (days/year); ED—exposure duration (years); BW—body weight (kg); and AT—averaging time (ED in years $\times 365$ days/year, in days; for non-carcinogens ED $=24$ years, for carcinogens $\mathrm{ED}=70$ years, [66]). The exposure parameters, used for the risk assessment calculations under the resident scenario, are given in Table S3.

To determine the non-carcinogenic and carcinogenic risks for the residents of Kraków, arising from their contacts with roof runoff, the $\mathrm{HQ}$ and $\mathrm{CR}$ values were calculated, respectively. The values of hazard indices (HQ) were calculated, using Equation (6) [64], and the values of carcinogenic risk (CR) were calculated, using Equation (7) [64].

$$
\begin{aligned}
& \mathrm{HQ}=\mathrm{ADD} / \mathrm{RfD}, \\
& \mathrm{CR}=\mathrm{ADD} \times \mathrm{SF},
\end{aligned}
$$

where: $\mathrm{HQ}$ - hazard quotient (unitless); $\mathrm{CR}$ —carcinogenic risk (unitless); ADD—average daily dose (mg/kg-day), RfD—reference dose (mg/kg-day); and SF-slope factor $\left((\mathrm{mg} / \mathrm{kg} \text {-day })^{-1}\right)$. For dermal contact, the reference doses $\left(\mathrm{RfD}_{\mathrm{d}}\right)$ and slope factor values $\left(\mathrm{SF}_{\mathrm{d}}\right)$ were calculated according to Equations (8) and (9), respectively [67]:

$$
\begin{gathered}
\mathrm{RfD}_{\mathrm{d}}=\mathrm{RfD}_{\mathrm{o}} / \mathrm{ABS}_{\mathrm{GI}}, \\
\mathrm{SF}_{\mathrm{d}}=\mathrm{SF}_{\mathrm{o}} \times \mathrm{ABS}_{\mathrm{GI}},
\end{gathered}
$$

where $\mathrm{ABS}_{\mathrm{GI}}$ is a fraction of contaminant, absorbed in the gastrointestinal tract (unitless). The values of toxicological parameters, used for the calculations of the resident scenario risk assessment, are given in Table S4.

The target risk value was set to be equal to $1(\mathrm{HQ}=1)$ for non-carcinogenic risk, with respect to both particular the element being investigated (individual HQ values) and total non-carcinogenic risk, defined as the sum of all $\mathrm{HQ}$ values calculated. As for carcinogenic risk, the acceptable risk level was set to be equal to $1 \times 10^{-6}$ for a particular contaminant $[64,68]$.

\subsubsection{Microbial Risk Assessment (MRA)}

Microbial risk assessment, in the context of infection by potentially pathogenic microorganisms, is based on the Quantitative Microbiological Risk Assessment (QMRA) methods, combining concentration of a particular pathogen in water (e.g., Campylobacter jejuni, Listeria sp., Salmonella enterica, pathogenic species of Escherichia coli, usually O157:H7 strain), dose-response models and potential exposure [69-72]. Since pathogenic strains had not been determined during the present study, except for the total amount of heterotrophic bacteria and fungi, our microbial risk assessment was based on the comparison of the results obtained and the statutory data proposed in regulations, as well as the results of other studies. According to the authors' best knowledge, there are neither Polish nor European regulations regarding acceptable amounts of total heterotrophic bacteria or fungi in roof runoff. Usually, the roof runoff criteria are compared to the drinking-water criteria, and that is consistent in Polish and European laws that allow for up to $100 \mathrm{CFU} / \mathrm{mL}$ of bacteria, although there is no relevant threshold for fungi.

\section{Results and Discussion}

\subsection{Contents of Pollutants in Roof Runoff}

The contents of 10 of 31 examined parameters (i.e., As, B, Co, Cr, Fe, Hg, Li, Mn, Ni and Se) were below the limit of quantification (LOQ) in the majority of the roof runoff samples (Table S5), and thus, they are not considered in further data analysis and discussion in this section. The contents of the remaining 21 investigated elements, measured in the Kraków roof runoff samples, during the sampling campaign from May 2019 to February 2020, are presented in Table 1. 
Table 1. Statistical parameters, and permissible levels of the selected elements in the roof runoff samples, investigated in Kraków (KR1-KR5) in 2019/2020 season.

\begin{tabular}{|c|c|c|c|c|c|c|c|c|c|}
\hline Parameter & Unit & Min & Max & Mean * & $\begin{array}{l}\text { Drinking Water } \\
\text { Standards } \\
\text { US EPA [62] }\end{array}$ & $\begin{array}{l}\text { Drinking Water } \\
\text { Guidelines } \\
\text { WHO [73] }\end{array}$ & $\begin{array}{c}\text { Drinking Water } \\
\text { Standards, Polish } \\
\text { Ministry of Health [74] }\end{array}$ & $\begin{array}{c}\text { Surface Water } \\
\text { Category A3 [75] }\end{array}$ & $\begin{array}{l}\text { Harmful Substances } \\
\text { Discharged to } \\
\text { Runoff [76] }\end{array}$ \\
\hline Bacteria & $\mathrm{CFU} / \mathrm{mL}$ & 500 & 124,000 & 22,761 & nd & nd & 100 & nd & nd \\
\hline Fungi & $\mathrm{CFU} / \mathrm{mL}$ & 0 & 3000 & 498 & nd & nd & nd & nd & nd \\
\hline $\mathrm{pH}$ & - & 6.3 & 7.6 & 6.8 & $6.5-8.5$ & nd & $6.5-9.5$ & $5.5-9.0$ & $6.5-9.0$ \\
\hline EC & $\mu \mathrm{S} / \mathrm{cm}$ & 8.8 & 58.8 & 26.1 & nd & nd & 2500 & 1000 & nd \\
\hline $\mathrm{Cl}^{-}$ & $\mathrm{mg} / \mathrm{L}$ & $<\mathrm{LOQ}$ & 5.56 & 1.72 & 250 & nd & 250 & 250 & 1000 \\
\hline $\mathrm{N}-\mathrm{NO}_{3}$ & $\mathrm{mg} / \mathrm{L}$ & 0.044 & 0.748 & 0.277 & 10 & 50 & 50 & 50 & 30 \\
\hline $\mathrm{P}_{-}-\mathrm{PO}_{4}$ & $\mathrm{mg} / \mathrm{L}$ & 0.014 & 0.237 & 0.045 & nd & nd & nd & nd & nd \\
\hline $\mathrm{SO}_{4}^{2-}$ & $\mathrm{mg} / \mathrm{L}$ & $<\mathrm{LOQ}$ & 8.751 & 2.230 & 250 & nd & 250 & 250 & 500 \\
\hline $\mathrm{SiO}_{2}$ & $\mathrm{mg} / \mathrm{L}$ & 0.316 & 0.752 & 0.418 & nd & nd & nd & nd & nd \\
\hline $\mathrm{Ag}$ & $\mathrm{mg} / \mathrm{L}$ & $<\mathrm{LOQ}$ & 0.0761 & 0.0170 & 0.1 & 0.9 & 0.01 & nd & 0.1 \\
\hline Al. & $\mathrm{mg} / \mathrm{L}$ & $<\mathrm{LOQ}$ & 0.0412 & 0.0091 & 0.2 & nd & 0.2 & nd & 3 \\
\hline $\mathrm{Ba}$ & $\mathrm{mg} / \mathrm{L}$ & $<\mathrm{LOQ}$ & 0.0168 & 0.0039 & 2 & 1.3 & nd & nd & 2 \\
\hline $\mathrm{Ca}$ & $\mathrm{mg} / \mathrm{L}$ & 0.1726 & 2.0801 & 0.6096 & nd & nd & nd & nd & nd \\
\hline $\mathrm{Cu}$ & $\mathrm{mg} / \mathrm{L}$ & $<$ LOQ & 0.0199 & 0.0054 & 1 & 2 & 2 & 0.5 & 0.5 \\
\hline K & $\mathrm{mg} / \mathrm{L}$ & 0.0867 & 1.0708 & 0.3649 & nd & nd & nd & nd & 80 \\
\hline $\mathrm{Mg}$ & $\mathrm{mg} / \mathrm{L}$ & 0.0241 & 0.1175 & 0.0602 & nd & nd & 125 & nd & nd \\
\hline Mo & $\mathrm{mg} / \mathrm{L}$ & $<\mathrm{LOQ}$ & 0.0307 & 0.0054 & $0.07^{1}$ & 0.006 & nd & nd & 1 \\
\hline $\mathrm{Na}$ & $\mathrm{mg} / \mathrm{L}$ & 0.4682 & 1.4067 & 0.7649 & 20 & nd & 200 & nd & 800 \\
\hline $\mathrm{Pb}$ & $\mathrm{mg} / \mathrm{L}$ & $<\mathrm{LOQ}$ & 0.0058 & 0.0026 & nd & 0.01 & 0.01 & 0.05 & 0.5 \\
\hline $\mathrm{Sb}$ & $\mathrm{mg} / \mathrm{L}$ & $<\mathrm{LOQ}$ & 0.0031 & 0.0008 & 0.006 & 0.02 & 0.005 & nd & 0.3 \\
\hline $\mathrm{Zn}$ & $\mathrm{mg} / \mathrm{L}$ & 0.0651 & 2.5786 & 0.6826 & 5 & nd & nd & 5 & 2 \\
\hline
\end{tabular}

CFU—colony forming units; US EPA—US Environmental Protection Agency; WHO—World Health Organization; nd—not determined; ${ }^{1}$ [77]; $<$ LOQ were substituted with LOQ/2 in calculations of mean values $[60,78] ;<\mathrm{LOQ}-$ below the limit of quantification. 
The amounts of bacteria and fungi in the Kraków city roof runoff varied both in terms of season and sampling sites, but no distinct patterns were identified, although bacteria were clearly more abundant (Table 1, Table S5). The mean value of the bacteria content was the lowest during the spring of 2019 (3140 CFU/mL) and the highest in the winter of $2020(47,590 \mathrm{CFU} / \mathrm{mL})$, while in case of fungi, the mean value was the lowest in the autumn of $2019(105 \mathrm{CFU} / \mathrm{mL})$ and the highest in the winter of 2020 (1090 CFU/mL). The data did not correspond to those obtained in reference site (MOG-Figure 1, Table S5), where the highest amounts of both bacteria and fungi were detected during autumn 2019, and the lowest ones in spring 2019 (in case of bacteria) or in winter 2020 (in case of fungi). All these emphasized the absence of any trend in term of microbiological contamination of roof runoff.

As the composition of roof runoff reflects the composition of the air, those two could be expected to be consistent. The unpublished data from 2018 on the microbiological contamination of the air in Kraków and two other nearby, smaller towns (Oświęcim and Brzesko) showed that the amounts of airborne microorganisms were also highly variable throughout the year, without a distinct pattern. However, the mean fungi quantity was clearly higher than the mean bacteria quantity in all three sampled cities (unlike in the case of roof runoff samples). The observed differences are probably due to a large diversity of factors influencing bioaerosols remaining in the air [29], like temperature, insolation, relative humidity, amount of rainfall, wind, plant cover, traffic, bioaerosol particle size and shape, and some others. The lowest amounts of both bacteria and fungi in the Kraków air were observed in the winter season, which is not consistent with data on microbial composition of roof runoff but stays in line with other studies regarding microbial air quality. The lowest concentrations of bacteria were detected in the Kraków air in winter also by Grzyb and Frączek [79] and by Bragoszewska and Pastuszka [80] in the city of Gliwice, Poland. The inconsistency of the results obtained for air and roof runoff is probably caused by the abundance of factors affecting both components. Evans et al. [81,82] and Sazakli et al. [83] demonstrated that the (micro)biological condition of roof runoff was mainly affected by weather conditions, like the effects of wind and rainfall. Relatively high amounts of microbiological contaminants detected in Kraków roof runoff with relatively low amounts detected in the air (observed during winter season) may be simply the effect of leaching air bioaerosols by rainfall. Moreover, roof runoff composition was found to be influenced by land use and the characteristics of catchment areas, as well as the technical condition of roofs and the types of roof decking, from which water was harvested $[1,30,31]$.

As the roof runoff samples were collected from gutters in Kraków, water had previously washed roof surfaces and collected debris from gutter systems. Therefore, it might contain microorganisms connected with such contaminants, as e.g., feces of birds, mammals, and insects, or putrid leaves [84-86], not only those contaminants that were typically airborne. The taxonomic identification of strains was beyond the scope of this study; however, it was observed that the majority of the colonies of isolated bacteria were colorful (usually yellow, orange, pink or red). That is typical for airborne microbes, as pigmentation provides better protection against permanent outdoor radiation (especially UV) and prolongs bacterial survival it the air [87]. That observation indicated that the harvested microorganisms originated mostly from the air. Furthermore, Evans et al. [81,82] noted that airborne microorganisms were significant contributors to the total amount of bacteria detected in the roof-harvested runoff. Moreover bird- and other animal-linked microbiological contamination of roof runoff was considered to be more prevalent in rural rather than urban catchment areas [1]. That observation stays in line with the conclusion stated above, concerning differences between the amounts of microorganisms detected in the air and in the roof runoff in Kraków. It seems then that the main source of microbiological contaminants in the harvested rainwater was bioaerosol washed out from the air, which led to relatively low amounts of microorganisms detected in the air during "wet" seasons.

Relatively small amounts of fungi (in comparison to those of bacteria) in the Kraków roof runoff (as well as in the case of the Mogilany (MOG) sampling point) may have resulted from the weather conditions. Fungal spores are significant and usually the most abundant contributor to bioaerosol in rural and urban air [88-90], and although fungi are known to "like" humidity, they prefer 
rather high temperatures and sunny weather. Therefore, spore production may decrease in rainy periods [91,92] and that could be a reason for their relatively small concentrations in Kraków roof runoff, when compared to bacteria. The amount of the detected microorganisms may be also affected by the time elapsed from the beginning of rainfall to the time of sampling, as rain washes the air and the highest microbial concentrations are observed in the first flush of roof runoff $[84,93]$. The other factor that may influence microbiological composition of roof runoff is the air-dust particle size, as particular biological objects are associated with various particle fractions [94]. It was demonstrated that the amount of microorganisms in the air was correlated with particular dust fractions [79,95].

In this study, the $\mathrm{pH}$ values of roof runoff in Kraków were in the range of 6.3-7.6. Mean pH values were similar in all sampling periods between 2019 and 2020: 6.7 in the spring of 2019, 6.8 in the autumn of 2019, and 6.9 in the winter of 2020. In the period from 2019 to 2020, a significant decrease in the average values of most physio-chemical parameters (with sufficient data collection) was observed, and those were (in brackets: mean values for the spring of 2019 and the winter of 2020, respectively, in $\mathrm{mg} / \mathrm{L}$, unless otherwise stated): $\mathrm{EC}(31.3,19.6 \mu \mathrm{S} / \mathrm{cm}), \mathrm{N}^{-\mathrm{NO}_{3}}(0.337,0.202)$, $\mathrm{P}^{-\mathrm{PO}_{4}}(0.081,0.023), \mathrm{Ag}(0.0336,<\mathrm{LOQ}), \mathrm{Al}(0.0158,<\mathrm{LOQ}), \mathrm{Ba}(0.0049,0.0030), \mathrm{Mo}(0.0106,<\mathrm{LOQ})$, $\mathrm{Pb}(0.0051,<\mathrm{LOQ})$, and $\mathrm{Sb}(0.0016,<\mathrm{LOQ})$. Our results are in line with research by Kotowski et al. [22] that indicated a constant decrease in the concentration of chemical components in air and precipitation in Kraków between 1996 and 2017. In addition, the results obtained by Traczyk and Gruszecka-Kosowska [33] revealed the improvement of air quality in Kraków between 2005 and 2020. According to that publication, the reasons of that trend included industrial, economic, and social changes occurring in Kraków. A significant improvement in air quality, and associated roof runoff quality, in the period from May 2019 to February 2020, could also be related to the fact that a total ban on the use of solid fuels in boiler houses, stoves, and fireplaces was imposed in Kraków on 1 September 2019 [96].

Our research also showed that values of such parameters as $\mathrm{EC}, \mathrm{N}-\mathrm{NO}_{3}, \mathrm{SO}_{4}{ }^{2-}, \mathrm{SiO}_{2}, \mathrm{Ca}, \mathrm{K}, \mathrm{Mg}$, $\mathrm{Na}$, and $\mathrm{Zn}$ in roof runoff mainly depended on the location of sampling, rather than the season of the year. Pollutant concentrations in the roof runoff are also correlated with the amount of rainfall as heavy rainfall dilutes the precipitation. The relevant parameters were definitely higher in eastern Kraków (District 4-KR2), which is an industrial section of the city, than in other sections (Figure 1, Table S5). The only parameter that seems to be influenced by season rather than sampling location, was concentration of chlorides, which was the highest during the winter of 2020. That could have been probably caused by the use of salt for road de-icing [97,98].

The results of the measurements, taken at the reference site in Mogilany (MOG—Figure 1, Table S5), revealed that the mean acidity of samples $(\mathrm{pH}=6.1)$ was lower than that observed in the roof runoff water collected in Kraków. Higher mean concentrations of such parameters as $\mathrm{Cl}^{-}, \mathrm{N}-\mathrm{NO}_{3}, \mathrm{P}_{-} \mathrm{PO}_{4}$ that were observed in Mogilany, could have been caused by more intensive de-icing and fertilization outside the city. On the other hand higher mean contents of $\mathrm{Ca}, \mathrm{K}, \mathrm{Pb}$, and $\mathrm{Zn}$ were observed in Kraków than in the reference site, which could have been related to intensive traffic and industrial sources of pollution [99].

A comparison with rainwater taken directly from the rooftop would give additional information on the quality of the rainwater. However, it was not possible to take such samples for comparative analysis in Kraków. Our mean results from the research conducted in 2019/2020 in Kraków were compared to the results obtained for other cities in Poland (Table 2), by the Chief Inspectorate of Environmental Protection in Poland [78]. That revealed that precipitation in Kraków was characterized by comparable values of most parameters, while $\mathrm{EC}, \mathrm{Cl}^{-}, \mathrm{SO}_{4}{ }^{2-}, \mathrm{Pb}$, and $\mathrm{Zn}$ were usually a bit higher. Emissions from steelworks and waste-treatment plant facilities were indicated as main sources of metals in roof runoff in Poznań [100]. An important role in increasing concentrations of pollutants in the atmosphere was also assigned to mining and industrial activities, responsible for increasing concentration of metals in ambient air and precipitation [61]. 
Table 2. Contents of the selected elements identified in the rainwater in Polish cities.

\begin{tabular}{|c|c|c|c|c|c|c|c|}
\hline Parameter & Unit & Kraków * & Gdańsk ** & Toruń ** & Białystok ** & Zielona Góra ** & Katowice ** \\
\hline $\mathrm{pH}$ & - & 6.8 & 6.13 & 7.05 & 5.42 & 5.35 & 4.73 \\
\hline EC & $\mu \mathrm{S} / \mathrm{cm}$ & 26.1 & 15.9 & 23.7 & 12.8 & 13.0 & 31.4 \\
\hline $\mathrm{Cl}^{-}$ & $\mathrm{mg} / \mathrm{L}$ & 1.72 & 1.54 & 1.17 & 0.45 & 1.12 & 2.83 \\
\hline $\mathrm{SO}_{4}^{2-}$ & $\mathrm{mg} / \mathrm{L}$ & 2.725 & 1.23 & 2.43 & 1.08 & 1.12 & 2.77 \\
\hline $\mathrm{Ca}$ & $\mathrm{mg} / \mathrm{L}$ & 0.6096 & 0.635 & 1.645 & 0.480 & 0.290 & 1.255 \\
\hline $\mathrm{Cu}$ & $\mathrm{mg} / \mathrm{L}$ & 0.0054 & 0.0064 & 0.0075 & 0.0077 & 0.0189 & 0.0107 \\
\hline K & $\mathrm{mg} / \mathrm{L}$ & 0.3649 & 0.745 & 0.215 & 0.100 & 0.310 & 0.265 \\
\hline $\mathrm{Mg}$ & $\mathrm{mg} / \mathrm{L}$ & 0.0602 & 0.090 & 0.290 & 0.075 & 0.070 & 0.140 \\
\hline $\mathrm{Na}$ & $\mathrm{mg} / \mathrm{L}$ & 0.7649 & 0.750 & 0.900 & 0.215 & 0.480 & 0.645 \\
\hline $\mathrm{Pb}$ & $\mathrm{mg} / \mathrm{L}$ & 0.0026 & 0.0005 & 0.0004 & 0.0007 & 0.0016 & 0.0074 \\
\hline $\mathrm{Zn}$ & $\mathrm{mg} / \mathrm{L}$ & 0.6826 & 0.0890 & 0.0555 & 0.1260 & 0.0370 & 0.2635 \\
\hline
\end{tabular}

* Mean results in the roof runoff samples, investigated in 2019/2020 season; ** Data based on the results of the Chief Inspectorate of Environmental Protection in 2018 [78]; <LOQ—below the limit of quantification.

Table 3. Contents of the investigated elements identified in the roof runoff samples, without and after acid digestion, from research conducted in the winter of 2020.

\begin{tabular}{|c|c|c|c|c|c|c|c|}
\hline Parameter & Sample & KR 1 & KR 2 & KR 3 & KR 4 & KR 5 & MOG \\
\hline & & \multicolumn{6}{|c|}{$\mathrm{mg} / \mathrm{L}$} \\
\hline \multirow{2}{*}{$\mathrm{P}-\mathrm{PO}_{4}$} & roof runoff & 0.016 & 0.029 & 0.027 & 0.025 & 0.016 & 0.018 \\
\hline & roof runoff after acid digestion & 0.292 & 0.298 & 0.369 & 0.438 & 0.279 & 0.409 \\
\hline \multirow{2}{*}{$\mathrm{SO}_{4}{ }^{2-}$} & roof runoff & 0.544 & 8.751 & 0.518 & 1.085 & $<$ LOQ & 0.701 \\
\hline & roof runoff after acid digestion & 0.590 & 7.316 & $<\mathrm{LOQ}$ & 1.211 & $<\mathrm{LOQ}$ & 0.813 \\
\hline \multirow{2}{*}{$\mathrm{SiO}_{2}$} & roof runoff & 0.328 & 0.752 & 0.364 & 0.330 & 0.316 & 0.349 \\
\hline & roof runoff after acid digestion & 0.952 & 1.125 & 0.834 & 2.147 & 0.572 & 2.129 \\
\hline \multirow{2}{*}{$\mathrm{Al}$} & roof runoff & $<$ LOQ & $<$ LOQ & $<$ LOQ & $<$ LOQ & $<$ LOQ & 0.0069 \\
\hline & roof runoff after acid digestion & 0.0641 & 0.0354 & 0.0454 & 0.2150 & $0.018 \overline{7}$ & 0.1701 \\
\hline \multirow{2}{*}{$\mathrm{Ba}$} & roof runoff & 0.0007 & 0.0066 & 0.0022 & 0.0013 & 0.0042 & 0.0010 \\
\hline & roof runoff after acid digestion & 0.0058 & 0.0093 & 0.0036 & 0.0083 & 0.0059 & 0.0075 \\
\hline \multirow{2}{*}{$\mathrm{Ca}$} & roof runoff & 0.1726 & 2.0801 & 0.2514 & 0.2839 & 0.2602 & 0.3571 \\
\hline & roof runoff after acid digestion & 0.8912 & 4.5606 & 1.2786 & 1.2980 & 0.5058 & 0.8167 \\
\hline \multirow{2}{*}{ Co } & roof runoff & $<\mathrm{LOQ}$ & $<\mathrm{LOQ}$ & $<$ LOQ & $<\mathrm{LOQ}$ & $<\mathrm{LOQ}$ & $<\mathrm{LOQ}$ \\
\hline & roof runoff after acid digestion & 0.0004 & 0.0003 & 0.0004 & 0.0004 & $<\mathrm{LOQ}$ & 0.0002 \\
\hline \multirow{2}{*}{$\mathrm{Cr}$} & roof runoff & $<\mathrm{LOQ}$ & $<\mathrm{LOQ}$ & $<$ LOQ & $<\mathrm{LOQ}$ & $<\mathrm{LOQ}$ & $<$ LOQ \\
\hline & roof runoff after acid digestion & $<\mathrm{LOQ}$ & $<\mathrm{LOQ}$ & $<$ LOQ & $<\mathrm{LOQ}$ & $<\mathrm{LOQ}$ & $<$ LOQ \\
\hline \multirow{2}{*}{$\mathrm{Cu}$} & roof runoff & $<\mathrm{LOQ}$ & $<\mathrm{LOQ}$ & 0.0199 & $<\mathrm{LOQ}$ & $<\mathrm{LOQ}$ & $<\mathrm{LOQ}$ \\
\hline & roof runoff after acid digestion & 0.0913 & 0.0020 & 0.0049 & 0.0051 & 0.0016 & 0.0067 \\
\hline \multirow{2}{*}{$\mathrm{Fe}$} & roof runoff & $<\mathrm{LOQ}$ & $<\mathrm{LOQ}$ & 0.0127 & 0.0141 & $<\mathrm{LOQ}$ & $<\mathrm{LOQ}$ \\
\hline & roof runoff after acid digestion & 0.4416 & 0.2028 & 0.3465 & 1.0458 & 0.1869 & 0.7817 \\
\hline \multirow{2}{*}{ K } & roof runoff & 0.0867 & 1.0708 & 0.3701 & 0.1576 & 0.1395 & 0.1539 \\
\hline & roof runoff after acid digestion & 0.1428 & 0.9583 & 0.4245 & 0.2588 & 0.1416 & 0.2848 \\
\hline \multirow{2}{*}{$\mathrm{Mg}$} & roof runoff & 0.0241 & 0.1175 & 0.0399 & 0.0683 & 0.0513 & 0.0616 \\
\hline & roof runoff after acid digestion & 0.1419 & 0.2235 & 0.2012 & 0.3978 & 0.0800 & 0.1855 \\
\hline \multirow{2}{*}{ Mn } & roof runoff & $<\mathrm{LOQ}$ & $<\mathrm{LOQ}$ & $<$ LOQ & $<\mathrm{LOQ}$ & $<$ LOQ & $<\mathrm{LOQ}$ \\
\hline & roof runoff after acid digestion & 0.0122 & 0.0091 & 0.0110 & 0.0225 & 0.0056 & 0.0211 \\
\hline \multirow{2}{*}{ Mo } & roof runoff & $<$ LOQ & $<$ LOQ & $<$ LOQ & $<$ LOQ & $<$ LOQ & 0.0010 \\
\hline & roof runoff after acid digestion & $<\mathrm{LOQ}$ & $<\mathrm{LOQ}$ & $<\mathrm{LOQ}$ & 0.0011 & 0.0072 & 0.0026 \\
\hline \multirow{2}{*}{$\mathrm{Na}$} & roof runoff & 0.4682 & 1.4067 & 0.7546 & 0.6873 & 0.5077 & 0.5979 \\
\hline & roof runoff after acid digestion & 0.6092 & 1.3551 & 0.6948 & 0.6388 & 0.4671 & 0.5911 \\
\hline \multirow[t]{2}{*}{$\mathrm{Ni}$} & roof runoff & $<\mathrm{LOQ}$ & 0.0010 & $<\mathrm{LOQ}$ & $<\mathrm{LOQ}$ & $<\mathrm{LOQ}$ & $<\mathrm{LOQ}$ \\
\hline & roof runoff after acid digestion & $<\mathrm{LOQ}$ & 0.0014 & $<$ LOQ & 0.0014 & $<\mathrm{LOQ}$ & 0.0014 \\
\hline \multirow{2}{*}{$\mathrm{Pb}$} & roof runoff & $<\mathrm{LOQ}$ & $<\mathrm{LOQ}$ & $<\mathrm{LOQ}$ & $<\mathrm{LOQ}$ & $<\mathrm{LOQ}$ & $<\mathrm{LOQ}$ \\
\hline & roof runoff after acid digestion & 0.0067 & 0.0001 & 0.0027 & $0.130 \overline{6}$ & $<\mathrm{LOQ}$ & 0.0135 \\
\hline \multirow{2}{*}{$\mathrm{Zn}$} & roof runoff & 0.1033 & 2.5786 & 0.0651 & 0.5040 & 0.1620 & 0.0153 \\
\hline & roof runoff after acid digestion & 0.4390 & 6.2382 & 0.3566 & 1.6012 & 0.2810 & 0.0644 \\
\hline
\end{tabular}

KR1-KR5-sampling sites located at the area of Kraków city; MOG-reference cite located in the village of Mogilany (Figure 1); $<$ LOQ— - below the limit of quantification.

The contents of elements in the roof runoff samples, collected during the winter of 2020, were investigated in parallel, (i) after filtration (raw) and (ii) after filtration and acid digestion. 
The analyses of the samples, extracted in concentrated nitric acid, indicated higher contents of the majority of elements, in comparison to their contents in raw samples (Table 3). Only for $\mathrm{SO}_{4}{ }^{2-}, \mathrm{K}$, and $\mathrm{Na}$ in both, raw and filtrated roof runoff samples and in roof runoff samples after filtration and acid digestion, differences in their contents were not clearly visible. Moreover, concentrations of $\mathrm{Cr}$ in the roof runoff samples were $<\mathrm{LOQ}$ in both types of samples. All that confirmed the importance of suspended matter in aqueous samples, also in the context of environmental risk from total contents of the investigated elements [101-103].

To determine the roof runoff quality, the element contents were compared to the drinking-water content standards, developed by the US EPA [62], the drinking-water guidelines, determined by the World Health Organization [73] and the Polish permissible levels for contaminants in surface water, designed for drinking purposes (Category A3) [75] (Table 1). The mean chemical contaminant contents, determined in roof runoff in the sampling campaigns of 2019-2020, did not exceed any threshold values determined by US EPA [62], WHO [73], and Poland [75]. Moreover, the mean contents of the investigated pollutants were compared to the threshold values of the harmful substances that can be discharged with roof runoff into the ground or aquatic environments, due to the Polish Regulation of the Minister of Maritime Economy and Inland Water Navigation [76]. Furthermore, in this comparison the mean contents of investigated pollutants, being present in the roof runoff samples, did not exceed the permissible levels of the harmful substances determined in [76], which indicated that the substances did not pose a threat to the environment. We can conclude, on the basis of the contents of chemical compounds analyzed here, that roof runoff can be potentially harvested from the territory of Kraków and designed for such applications, as watering, washing, and cleaning. Such practices are common in arid and semi-arid regions [104]. As regards microorganisms, there are no regulations concerning the microbial quality of roof runoff, and thus drinking water regulations are often applied. The Polish law, which is harmonized with the European law, allows for $100 \mathrm{CFU} / \mathrm{mL}$ of bacteria at $22^{\circ} \mathrm{C}$ [74]. In the light of that regulation, the Kraków roof runoff is highly contaminated and unsuitable for drinking, but it can possibly be used as a substitute of tap water for some non-potable purposes [13].

\subsection{Risk Assessment}

\subsubsection{Ecological Risk Assessment (ERA)}

In the ecological risk analysis, the element contents of the filtrated water samples were used. Consequently, the ecological risk values were below the acceptable level of one, indicating no risk. The values of toxicity potential (TP) of roof runoff, calculated on the basis of available drinking water standards, with respect to all the analyzed elements, were $<1$, revealing a lack of ecological risk (Table 4). To involve a higher number of elements in the ecological risk assessment, since the values for drinking water standards were not available for all elements, we used the values of contamination factor $(\mathrm{CF})$ and contamination degree $\left(\mathrm{C}_{\mathrm{deg}}\right)$ in our study. The calculated values of $\mathrm{CF}$, in the case of all analyzed elements, were $<1$ (Table 4), indicating, according to the Håkanson classification [63], a low contamination of roof runoff, with single elements. However, the value of $C_{d e g}$, calculated for all analyzed elements altogether, was equal to 9.44, indicating moderate contamination of roof runoff, analyzed in the 2019/2020 season, suggesting that negative impact on the environment might occur. The above also indicates that as the total risk is the sum partial risk values for investigated components the higher number of considered pollutants the higher total risk value, which further points the size of pollution. Thus, it reveals also that during comparison of total risk values the number of individual pollutant analyses should be considered. 
Table 4. Ecological risk values of roof runoff in Kraków.

\begin{tabular}{|c|c|c|}
\hline Parameter & Toxicity Potential (TP) & Contamination Factor (CF) \\
\hline Bacteria & - & 0.26 \\
\hline Fungi & - & 0.24 \\
\hline $\mathrm{pH}^{\circ}$ & $<1$ & 0.91 \\
\hline EC & - & 0.46 \\
\hline $\mathrm{Cl}^{-}$ & 0.007 & 0.34 \\
\hline $\mathrm{N}-\mathrm{NO}_{3}$ & 0.03 & 0.40 \\
\hline $\mathrm{P}-\mathrm{PO}_{4}$ & - & 0.28 \\
\hline $\mathrm{SO}_{4}^{2-}$ & - & 0.23 \\
\hline $\mathrm{SiO}_{2}$ & - & 0.53 \\
\hline $\mathrm{Ag}$ & - & 0.26 \\
\hline $\mathrm{Al}$ & 0.05 & 0.27 \\
\hline $\mathrm{Ba}$ & 0.002 & 0.28 \\
\hline $\mathrm{Ca}$ & - & 0.27 \\
\hline $\mathrm{Cu}$ & 0.005 & 0.28 \\
\hline $\mathrm{Fe}$ & 0.03 & 0.47 \\
\hline $\mathrm{Hg}$ & - & 0.27 \\
\hline $\mathrm{K}^{\circ}$ & - & 0.29 \\
\hline $\mathrm{Mg}$ & - & 0.46 \\
\hline $\mathrm{Mn}$ & 0.06 & 0.41 \\
\hline Mo & 0.08 & 0.22 \\
\hline $\mathrm{Na}$ & - & 0.50 \\
\hline $\mathrm{Ni}$ & 0.03 & 0.63 \\
\hline $\mathrm{Pb}$ & 0.18 & 0.34 \\
\hline $\mathrm{Zn}$ & 0.14 & 0.24 \\
\hline \multicolumn{2}{|c|}{ Contamination degree $\left(\mathrm{C}_{\mathrm{deg}}\right)$} & 9.44 \\
\hline
\end{tabular}

\subsubsection{Human Health Risk Assessment (HHRA)}

The main objective of the human health risk analyses was to gain the first impression of the total risk value, arising from the possible contact with roof runoff. Thus, the element contents after acid digestion (Table 3) were chosen to calculate the highest possible risk value according to the rule of the most conservative risk assumptions. As regards carcinogenic elements, only $\mathrm{Pb}$ was analyzed with respect to the existing toxicological parameters and determined element contents. The values of calculated average daily doses in the ingestion exposure pathway and of dermal absorbed doses in the dermal contact exposure pathway are presented in Table S6. The values of calculated carcinogenic and non-carcinogenic risk, as well as of the total risk, are presented in Table 5. The total non-carcinogenic risk values exceeded the acceptable level of one both in adults $(\mathrm{HQ}=1.38)$ and children $(\mathrm{HQ}=2.52)$. The pathway of dermal contact exposure to roof runoff had a dominant impact on the risk value in non-carcinogenic risk. In that exposure pathway, the decreasing risk of the investigated elements was found to be as follows: $\mathrm{Pb}>\mathrm{Cu}>\mathrm{Mo}>\mathrm{Co}>\mathrm{Ni}>\mathrm{Al}>\mathrm{Fe}>\mathrm{Mn}>\mathrm{Zn}>\mathrm{Ba}$. In the ingestion exposure pathway, the decreasing risk of the analyzed elements was ordered as follows: $\mathrm{Ni}>\mathrm{Pb}>\mathrm{Zn}>\mathrm{Co}>\mathrm{Fe}>\mathrm{Mn}>\mathrm{Cu}>\mathrm{Mo}>\mathrm{Al}>\mathrm{Ba}$. In the cases of individual carcinogenic elements, the acceptable level of $1 \times 10^{-6}$ for $\mathrm{Pb}$ was exceeded in the dermal contact exposure pathway (adults $\mathrm{CR}=4.87 \times 10^{-5}$, children $\mathrm{CR}=2.23 \times 10^{-5}$ ). Dermal contact was a dominant exposure pathway, in comparison to accidental ingestion of roof runoff. The results of health risk analysis indicated that both non-carcinogenic and carcinogenic risk values for investigated compounds exceeded the acceptable levels which suggests that contamination of rainfall water in urban agglomerations becomes an environmental threat that was confirmed in our risk assessment calculations for the dermal contact exposure pathway. Thus, it should be taken into account by residents of urban areas when planning a walk outside. However, pollutant contents taken for calculations referred to contents of roof water 
runoff, and thus they were not precisely the content in rainwater. Notwithstanding, according to conservative risk assessment principle, the worst case scenario was assessed.

Table 5. Human health risk assessment values for the residents of Kraków, in reference to roof runoff exposure pathways.

\begin{tabular}{|c|c|c|c|c|c|c|c|c|}
\hline \multirow{3}{*}{ Pollutant } & \multicolumn{4}{|c|}{ Ingestion } & \multicolumn{4}{|c|}{ Dermal Contact } \\
\hline & \multicolumn{2}{|c|}{ HQ } & \multicolumn{2}{|c|}{ CR } & \multicolumn{2}{|c|}{ HQ } & \multicolumn{2}{|c|}{ CR } \\
\hline & Adult & Child & Adult & Child & Adult & Child & Adult & Child \\
\hline $\mathrm{Al}$ & $1.18 \times 10^{-7}$ & $2.76 \times 10^{-7}$ & - & - & $2.07 \times 10^{-3}$ & $3.79 \times 10^{-3}$ & - & - \\
\hline $\mathrm{Ba}$ & $4.36 \times 10^{-8}$ & $1.02 \times 10^{-7}$ & - & - & $5.33 \times 10^{-5}$ & $9.79 \times 10^{-5}$ & - & - \\
\hline Co & $1.28 \times 10^{-6}$ & $2.98 \times 10^{-6}$ & - & - & $8.93 \times 10^{-3}$ & $1.64 \times 10^{-2}$ & - & - \\
\hline $\mathrm{Cu}$ & $6.01 \times 10^{-7}$ & $1.40 \times 10^{-6}$ & - & - & $2.83 \times 10^{-1}$ & $5.19 \times 10^{-1}$ & - & - \\
\hline $\mathrm{Fe}$ & $9.24 \times 10^{-7}$ & $2.16 \times 10^{-6}$ & - & - & $4.39 \times 10^{-4}$ & $8.06 \times 10^{-4}$ & - & - \\
\hline $\mathrm{Mn}$ & $7.32 \times 10^{-7}$ & $1.71 \times 10^{-6}$ & - & - & $7.38 \times 10^{-5}$ & $1.35 \times 10^{-4}$ & - & - \\
\hline Mo & $5.06 \times 10^{-7}$ & $1.18 \times 10^{-6}$ & - & - & $1.16 \times 10^{-1}$ & $2.13 \times 10^{-1}$ & - & - \\
\hline $\mathrm{Ni}$ & $4.58 \times 10^{-5}$ & $1.07 \times 10^{-4}$ & - & - & $6.40 \times 10^{-3}$ & $1.18 \times 10^{-2}$ & - & - \\
\hline $\mathrm{Pb}$ & $9.46 \times 10^{-6}$ & $2.21 \times 10^{-5}$ & $4.77 \times 10^{-10}$ & $2.78 \times 10^{-10}$ & $9.66 \times 10^{-1}$ & $1.77 \times 10^{0}$ & $4.87 \times 10^{-5}$ & $2.23 \times 10^{-5}$ \\
\hline $\mathrm{Zn}$ & $6.44 \times 10^{-6}$ & $1.50 \times 10^{-5}$ & - & - & $6.76 \times 10^{-5}$ & $1.24 \times 10^{-4}$ & - & - \\
\hline Total & $6.59 \times 10^{-5}$ & $1.54 \times 10^{-4}$ & $4.77 \times 10^{-10}$ & $2.78 \times 10^{-10}$ & $1.38 \times 10^{0}$ & $2.54 \times 10^{0}$ & $4.87 \times 10^{-5}$ & $2.23 \times 10^{-5}$ \\
\hline Adult total HQ & \multicolumn{8}{|c|}{$1.38 \times 10^{0}$} \\
\hline Child total HQ & \multicolumn{8}{|c|}{$2.54 \times 10^{0}$} \\
\hline Adult total CR & \multicolumn{8}{|c|}{$4.87 \times 10^{-5}$} \\
\hline Child total CR & \multicolumn{8}{|c|}{$2.23 \times 10^{-5}$} \\
\hline
\end{tabular}

HQ—hazard quotient; CR—cancer risk; - not applicable to the available data.

\subsubsection{Microbial Risk Assessment (MRA)}

The microbial contamination of the roof runoff is considered to be the most hazardous, regarding human health risk assessment. The greatest microbial risk is associated with enteric pathogens, causing gastrointestinal illnesses, similarly to viruses, bacteria, protozoa or helminths that are introduced into water by contamination with human and animal feces or with decay products [93]. Microbiological hazard is also associated with skin, eye, or respiratory tract irritation, as a result of dermal contact or bioaerosol inhalation [81]. The microbiological quality assessment of the Kraków roof runoff was difficult to attain, as neither Polish nor European regulations, determining allowable amounts of total heterotrophic bacteria and fungi in roof runoff, were available. Therefore, the drinking water regulations were referred to instead. The Polish and European laws are consistent in that point and allow $100 \mathrm{CFU} / \mathrm{mL}$ of bacteria at $22{ }^{\circ} \mathrm{C}$, but do not determine any relevant amounts of fungi (Table 1). In the light of those regulations, the Kraków roof runoff is highly contaminated by microorganisms and is unsuitable for drinking. The assessment of possible water use for some nonpotable purposes, as a substitute for tap water, is very hard to describe, due to a lack of relevant regulations. Moreover, while the data on various indicators or potentially pathogenic bacteria in roof runoff are abundant $[1,30,31]$, the data on the total heterotrophic bacteria and fungi are very scarce.

The amounts of fungi and bacteria in the Kraków roof runoff were significantly higher (1-3 orders of magnitude) than those established in Australia [81], Nigeria [103,105], and Palestine [106], as well as higher (but to a lesser extent) than those indicated in other Polish studies, conducted in Białystok [4]. The unpublished data on air quality in Kraków (mentioned above) may help to shed light on the microbiological assessment of roof runoff. The amount of microorganisms in the Kraków air, detected in the studies conducted in 2018, was 5-6 times higher in case of bacteria and 6-14 times higher in case of fungi, in comparison to the results obtained in two nearby smaller towns (Oświęcim and Brzesko). The air was assessed as either moderately $\left(1000<\mathrm{CFU} / \mathrm{m}^{3}<3000\right)$, or highly $\left(>3000 \mathrm{CFU} / \mathrm{m}^{3}\right)$ contaminated with bacteria, with respect to the Polish Standard PN-89/Z-04111/02 [107]). Regarding fungi (according to PN-89/Z-04111/03 [108]), the air was clean in winter $\left(<3000 \mathrm{CFU} / \mathrm{m}^{3}\right)$, and in other seasons characterized by pollution that may have negatively affected the human environment $\left(5000<\mathrm{CFU} / \mathrm{m}^{3}<10,000\right)$, or pollution the threatening human environment $\left(>10,000 \mathrm{CFU} / \mathrm{m}^{3}\right)$. The amounts of bacteria in Kraków, detected by 
Grzyb and Frączek [79], and in Poznań, detected by Bugajny et al. [89] were at similar levels, while the air in Gliwice [80] and Warszawa [109], was clearly less microbiologically contaminated. Plate counting of microorganisms, applied during this study, allowed us to evaluate the amounts of viable forms only. Although that method has been widely used in microbial studies, it is worth noting that real amounts of microorganisms in the environmental samples are much higher, since either some of microbes are not able to grow on artificial media, or are simply dead. Gołofit-Szymczak and Górny [109] demonstrated that viable forms constituted only up to $0.3 \%$ of all microorganisms detected in the air. However, it is known that even dead microorganism may cause irritation of skin, eyes, or respiratory tract, owing to the presence of allergens or toxins in their cells [110], posing a serious threat to human health.

Although the physical and chemical quality of the Kraków roof runoff is generally good, its microbiological condition is much more disturbing and disqualifies roof runoff from potable use, without previous treatment. Approximate results, leading to similar conclusions, were obtained by Daoud et al. [106].

\section{Conclusions}

Our studies involved the investigation of the chemical and biological condition of roof runoff samples, collected during the period from the spring of 2019 to the winter of 2020. The results of our studies revealed that the element and chemical compound contents were found mainly in suspensions, and such contents were lower in dissolved forms of the aqueous phase. It was established that the quality of the examined roof runoff samples depended on sites, while the sampling period had lower influence on the samples' compositions. The concentrations of the investigated chemical components were higher in the industrial district of Kraków than those collected in other parts of the city. The present research project showed that the concentrations of the majority of chemical components, found in roof runoff, significantly decreased with time. To a large extent, that indicated a connection with a total ban on coal and other solid fuel burning in Kraków, implemented on 1 September 2019. The contents of the investigated parameters did not exceed the permissible recommended values for drinking water, indicating that roof runoff could be potentially harvested for non-potable applications, like plant watering. As regards the contents of particularly harmful substances, being present in the roof runoff samples, it was stated that the analyzed roof runoff samples did not pose a threat to the environment. The results of our ecological risk analysis revealed no risk of individual elements, with respect to the values of the toxicity potential and contamination factor. However, the contamination degree of all analyzed elements altogether, indicated moderate contamination of roof runoff. In addition, our human health risk assessment revealed that the acceptable non-carcinogenic risk was exceeded in the dermal contact exposure pathway, in the cases of $\mathrm{Pb}, \mathrm{Cu}$, and $\mathrm{Mo}$, while the non-carcinogenic risk, in the case of $\mathrm{Pb}$. Although microbial risk could not be assessed quantitatively, it was found to be high, in respect of the total amount of viable forms of fungi and bacteria, in comparison to the amounts stated in the drinking-water regulations. The results obtained by us indicated that the roof runoff quality should be taken into consideration in other relevant risk analyses, as it generates significant contribution to risk values, especially in urban environments, as it represents significant air pollution levels.

Supplementary Materials: The following are available online at http://www.mdpi.com/2076-3417/10/23/8554/s1, Table S1. Description of the investigated parameters, with analytical methods and standards used in this study. Table S2. Measuring parameters of ICP spectrometers, used in this study. Table S3. Exposure parameters, used for the risk assessment calculations under the resident scenario in this study. Table S4. Toxicological parameters, used for the risk assessment calculations under the resident scenario in this study. Table S5. Concentration of parameters investigated in roof-harvested rainwater on the Kraków area in 2019/2020 season. Table S6. Estimated daily intake values for the residents of Kraków, in reference to rainwater exposure pathways.

Author Contributions: Conceptualization, M.S., A.G.-K., and A.K.; methodology, M.S., A.G.-K., and A.K.; validation, M.S. and A.K.; formal analysis, M.S., A.G.-K., and A.K.; investigation, M.S., A.G.-K., and A.K.; resources, M.S., A.G.-K., and A.K.; data curation, M.S., A.G.-K., and A.K.; writing-original draft preparation, M.S., A.G.-K., and A.K.; writing-review and editing, M.S., A.G.-K., and A.K.; visualization, A.K.; supervision, A.G.-K.; project administration, M.S., A.G.-K., and A.K.; funding acquisition, M.S., A.G.-K., and A.K. All authors have read and agreed to the published version of the manuscript. 
Funding: This research was funded by the AGH University of Science and Technology, Statutory Research grant number 16.16.140.315. The APC was funded by the AGH University of Science and Technology.

Conflicts of Interest: The authors declare no conflict of interest.

\section{References}

1. Gwenzi, W.; Dunjana, N.; Pisa, C.; Tauro, T.; Nyamadzawo, G. Water quality and public health risks associated with roof runoff harvesting systems for potable supply: Review and perspectives. Sustain. Water Qual. Ecol. 2015, 6, 107-118. [CrossRef]

2. Haider, H.; Abul Razzaq Ghumman, A.R.; Al-Salamah, I.S.; Ghazaw, Y.; Abdel-Maguid, R.H. Sustainability evaluation of roof runoff harvesting-based flood risk management strategies: A multilevel decision-making framework for arid environments. Arab. J. Sci. Eng. 2019, 44, 8465-8488. [CrossRef]

3. Sheikh, V. Perception of domestic roof runoff harvesting by Iranian citizens. Sustain. Cities Soc. 2020, 60, 102278. [CrossRef]

4. Struk-Sokołowska, J.; Gwoździej-Mazur, J.; Jadwiszczak, P.; Butarewicz, A.; Ofman, P.; Wdowikowski, M.; Kaźmierczak, B. The Quality of Stored Roof runoff for Washing Purposes. Water 2020, 12, 252. [CrossRef]

5. May, S.; Prado, R.T.A. Experimental evaluation of roof runoff quality for non-potable applications in the city of São Paulo, Brazil. Urban Water J. 2006, 3, 145-151. [CrossRef]

6. Stec, A.; Słyś, D. The Impact of Roof runoff Harvesting System Location on Their Financial Efficiency: A Case Study in Poland. In Water Management and the Environment: Case Studies; Zelenakova, M., Ed.; WINEC 2017, Water Science and Technology Library; Springer: Cham, Switzerland, 2018; Volume 86, pp. 43-63. [CrossRef]

7. Słyś, D. Potential of roof runoff utilization in residential housing in Poland. Water Environ. J. 2009, 23, 318-325. [CrossRef]

8. Starowicz, A.; Bryszewska-Mazurek, A. Roof runoff harvesting system in a multi-family building located in Poland. Pol. J. Nat. Sci. 2019, 34, 415-432.

9. Godyń, I.; Grela, A.; Stajno, D.; Tokarska, P. Sustainable Roof runoff Management Concept in a Housing Estate with a Financial Feasibility Assessment and Motivational Roof runoff Fee System Efficiency Analysis. Water 2020, 12, 151. [CrossRef]

10. Chapa, F.; Krauss, M.; Hack, J. A multi-parameter method to quantify the potential of roof runoff harvesting at regional levels in areas with limited rainfall data. Resour. Conserv. Recycl. 2020, 161, 104959. [CrossRef]

11. Nosrati, K. Identification of a water quality indicator for urban roof runoff. Sustain. Water Qual. Ecol. 2017, 9-10, 78-87. [CrossRef]

12. Goncalves, F.; Andrade, M.; Forti, M.; Astolfo, R.; Ramos, M.; Massambani, O.; Melfi, A. Preliminary estimation of the rainfall chemical composition evaluated through the scavenging modeling for north-eastern Amazonian region (Amapa State, Brazil). Environ. Pollut. 2003, 121, 63-73. [CrossRef]

13. Lye, D.J. Rooftop runoff as a source of contamination: A review. Sci. Tot. Environ. 2009, 407, 5429-5434. [CrossRef] [PubMed]

14. Forster, J. Variability of roof runoff quality. Water Sci. Technol. 1999, 39, 137-144. [CrossRef]

15. DeBusk, K.M.; Hunt, W.F.; Osmond, D.L.; Cope, G.W. Water quality of roof runoff: Implications for residential water harvesting systems. Urban Waterways 2011. Available online: https://content.ces.ncsu.edu/waterquality-of-rooftop-runoff (accessed on 14 October 2020).

16. Torres, A.; Méndez-Fajardo, S.; Gutiérrez Torres, A.G.; Sandoval, S. Quality of Rainwater Runoff on Roofs and Its Relation to Uses and Rain Characteristics in the Villa Alexandra and Acacias Neighborhoods of Kennedy, Bogota, Colombia. J. Environ. Eng. 2013, 139, 1273-1278. [CrossRef]

17. Jedrzejczak, M. Preliminary study of the toxicity of rainwater runoff from the roofs with varying coverage. Folia Pomer. Univ. Technol. Stetin. Agric. Aliment. Pisc. Zootech. 2016, 330, 101-112. [CrossRef]

18. Sultana, M.N.; Akib, S.; Ashraf, M.A. Thermal comfort and runoff water quality performance on green roofs in tropical conditions. Geol. Ecol. Landsc. 2017, 1, 47-55. [CrossRef]

19. Lee, C. Impacts of urban form on air quality: Emissions on the road and concentrations in the US metropolitan areas. J. Environ. Manag. 2019, 246, 192-202. [CrossRef]

20. Munir, S.; Mayfield, M.; Coca, D.; Jubb, S.A. Structuring an integrated air quality monitoring network in large urban areas-Discussing the purpose, criteria and deployment strategy. Atmos. Environ. 2019, 2, 100027. [CrossRef] 
21. Gulia, S.; Nagendra, S.M.S.; Barnes, J.; Khare, M. Urban local air quality management framework for non-attainment areas in Indian cities. Sci. Total Environ. 2018, 619-620, 1308-1318. [CrossRef]

22. Kotowski, T.; Motyka, J.; Knap, W.; Bielewski, J. A 17-Year study on the chemical composition of rain, snow and sleet in very dusty air (Kraków, Poland). J. Hydrol. 2020, 582, 124543. [CrossRef]

23. Keresztesi, A.; Nita, I.-A.; Birsan, M.-V.; Bodor, Z.; Pernyeszi, T.; Micheu, M.M.; Szép, R. Assessing the variations in the chemical composition of roof runoff and air masses using the zonal and meridional index. Atmos. Res. 2020, 237, 104846. [CrossRef]

24. Air Quality in Europe-2018 Report; EEA Report No 12/2018; Publications Office of the European Union: Luxembourg; European Environment Agency: København, Denmark, 2018.

25. Outdoor Air Pollution. IARC Monographs on the Evaluation of Carcinogenic Risks to Humans; World Health Organization: Geneva, Switzerland, 2016; Volume 109.

26. Pope, C.A., III; Dockery, D.W. Health Effects of Fine Particulate Air Pollution: Lines that Connect. J. Air Waste Manag. Assoc. 2006, 56, 709-742. [CrossRef] [PubMed]

27. Hamanaka, R.B.; Mutlu, G.M. Particulate Matter Air Pollution: Effects on the Cardiovascular System. Front. Endocrinol. 2018, 9, 680. [CrossRef]

28. Stetzenbach, L.D. Airborne Infectious Microorganisms. In Encyclopedia of Microbiology, 3rd ed.; Schaechter, M., Ed.; Academic Press: Cambridge, MA, USA, 2009; pp. 175-182. [CrossRef]

29. Stetzenbach, L.D.; Buttner, M.P.; Cruz, P. Detection and enumeration of airborne biocontaminants. Curr. Opin. Biotech. 2004, 15, 170-174. [CrossRef]

30. Sánchez, A.S.; Cohim, E.; Kalid, R.A. A review on physicochemical and microbiological contamination of roof-harvested roof runoff in urban areas. Sustain. Water Qual. Ecol. 2015, 6, 119-137. [CrossRef]

31. Hamilton, K.; Reyneke, B.; Waso, M.; Clements, T.; Ndlovu, T.; Khan, W.; DiGiovanni, K.; Rakestraw, E.; Montalto, F.; Haas, C.N.; et al. A global review of the microbiological quality and potential health risks associated with roof-harvested roof runoff tanks. Clean Water 2019, 2, 7. [CrossRef]

32. Rydin, Y.; Bleahu, A.; Davies, M.; Dávila, J.; Friel, S.; De Grandis, G.; Groce, N.; Hallal, P.; Hamilton, I.; Howden-Chapman, P.; et al. Shaping cities for health: Complexity and the planning of urban environments in the 21st century. Lancet 2012, 379, 2079-2108. [CrossRef]

33. Traczyk, P.; Gruszecka-Kosowska, A. The Condition of Air Pollution in Kraków, Poland, in 2005-2020, with Health Risk Assessment. Int. J. Environ. Res. Public Health 2020, 17, 6063. [CrossRef]

34. Brunt, H.; Jones, S.J. A pragmatic public health-driven approach to enhance local air quality management risk assessment in Wales, UK. Environ. Sci. Policy 2019, 96, 18-26. [CrossRef]

35. Piersanti, S.; Adani, M.; Briganti, G.; Cappelletti, A.; Ciancarella, L.; Cremona, G.; D’Isidoro, M.; Lombardi, C.; Pacchierotti, F.; Russo, F.; et al. Air quality modeling and inhalation health risk assessment for a new generation coal-fired power plant in Central Italy. Sci. Total Environ. 2018, 644, 884-898. [CrossRef] [PubMed]

36. Widziewicz, K.; Rogula-Kozłowska, W.; Loska, K.; Kociszewska, K.; Majewski, G. Health Risk Impacts of Exposure to Airborne Metals and Benzo(a)Pyrene during Episodes of High PM10 Concentrations in Poland. Biomed. Environ. Sci. 2018, 31, 23-36. [CrossRef] [PubMed]

37. Zgłobicki, W.; Telecka, M.; Skupiński, S. Assessment of short-term changes in street dust pollution with heavy metals in Lublin (E Poland)—Levels, sources and risks. Environ. Sci. Pollut. Res. 2019, 26, 35049-35060. [CrossRef] [PubMed]

38. Pachurka, Ł.; Gruszecka-Kosowska, A.; Kobus, D.; Sówka, I. Assessment of inhalational exposure of the residents of Wrocław, Kraków, and Warszawa to benzo[a]pyrene. Ecol. Chem. Eng. A 2018, 25, 39-49. [CrossRef]

39. Rogula-Kozłowska, W.; Klejnowski, K. Submicrometer Aerosol in Rural and Urban Backgrounds in Southern Poland: Primary and Secondary Components of PM1. Bull. Environ. Contam. Toxicol. 2013, 90, 103-109. [CrossRef] [PubMed]

40. Adamiec, E.; Jarosz-Krzemińska, E. Human Health Risk Assessment associated with contaminants in the finest fraction of sidewalk dust collected in proximity to trafficked roads. Sci. Rep. 2019, 9, 16364. [CrossRef] [PubMed]

41. WHO Ambient Air Pollution Database. May 2016; World Health Organization: Geneva, Switzerland, 2016.

42. Samek, L. Overall human mortality and morbidity due to exposure to air pollution. Int. J. Occup. Med. Environ. Health 2016, 29, 417-426. [CrossRef]

43. Gruszecka-Kosowska, A.; Wdowin, M. The mineralogy, geochemistry and health risk assessment of deposited particulate matter (PM) in Kraków, Poland. Geol. Geophys. Environ. 2016, 42, 429-441. [CrossRef] 
44. Adamiec, E. Road Environments: Impact of Metals on Human Health in Heavily Congested Cities of Poland. Int. J. Environ. Res. Public Health 2017, 14, 697. [CrossRef]

45. Gruszecka-Kosowska, A. Assessment of the Kraków inhabitants' health risk caused by the exposure to inhalation of outdoor air contaminants. Stoch. Environ. Res. Risk. Assess. 2018, 32, 485-499. [CrossRef]

46. ISO 10523. Water Quality_Determination of $p H$; International Organization for Standardization: Geneva, Switzerland, 2008.

47. ISO 7888. Water Quality-Determination of Electrical Conductivity; International Organization for Standardization: Geneva, Switzerland, 1985.

48. ISO 13395. Water Quality_Determination of Nitrite Nitrogen and Nitrate Nitrogen and the Sum of Both by Flow Analysis (CFA and FIA) and Spectrometric Detection; International Organization for Standardization: Geneva, Switzerland, 1996.

49. ISO 6878. Water Quality-Determination of Phosphorus-Ammonium Molybdate Spectrometric Method; International Organization for Standardization: Geneva, Switzerland, 2004.

50. ISO 9297. Water Quality-Determination of Chloride-Silver Nitrate Titration with Chromate Indicator (Mohr's Method); International Organization for Standardization: Geneva, Switzerland, 1989.

51. Method 3015A (SW-846): Microwave Assisted Acid Digestion of Aqueous Samples and Extracts; Revision 1; United States Environmental Protection Agency: Washington, DC, USA, 2007.

52. ISO 11885. Water Quality_Determination of Selected Elements by Inductively Coupled Plasma Optical Emission Spectrometry (ICP-OES); International Organization for Standardization: Geneva, Switzerland, 2007.

53. ISO 17294-2. Water Quality_Application of Inductively Coupled Plasma Mass Spectrometry (ICP-MS)—Part 2: Determination of Selected Elements Including Uranium Isotopes; International Organization for Standardization: Geneva, Switzerland, 2016.

54. ISO 6222. Water Quality_Enumeration of Culturable Micro-Organisms—Colony Count by Inoculation in a Nutrient Agar Culture Medium; International Organization for Standardization: Geneva, Switzerland, 1999.

55. ISO 8199. Water Quality-General Requirements and Guidance for Microbiological Examinations by Culture; International Organization for Standardization: Geneva, Switzerland, 2018.

56. Tomasiewicz, D.M.; Hotchkiss, D.K.; Reinbold, G.W.; Read, R.B.; Hartman, P.A. The most suitable number of colonies on plates for counting. J. Food Prot. 1980, 43, 282-286. [CrossRef] [PubMed]

57. Maturin, L.; Peeler, J.T. Bacteriological Analytical Manual; Chapter 3: Aerobic Plate Count; United States Food and Drug Administration: White Oak, MA, USA, 2001. Available online: https://www.fda.gov/food/ laboratory-methods-food/bam-chapter-3-aerobic-plate-count (accessed on 16 July 2020).

58. ISO 17294-1. Water Quality_Application of Inductively Coupled Plasma Mass Spectrometry (ICP-MS)—Part 1: General Guidelines; International Organization for Standardization: Geneva, Switzerland, 2004.

59. Method 6020B: Inductively Coupled Plasma-Mass Spectrometry; Revision 2; US Environmental Protection Agency: Washington, DC, USA, 1998. Available online: https://www.epa.gov/sites/production/files/2015-12/ documents/6020b.pdf (accessed on 15 January 2020).

60. GEMS/Food-EURO Second Workshop on Reliable Evaluation of Low-Level Contamination of Food: Report on a Workshop in the Frame of GEMS Food-EURO; World Health Organization: Geneva, Switzerland, 1995.

61. Keresztesi, A.; Nita, I.-A.; Birsan, M.-V.; Bodor, Z.; Szép, R. The risk of cross-border pollution and the influence of regional climate on the roof runoff chemistry in the Southern Carpathians, Romania. Environ. Sci. Pollut. Res. 2020, 27, 9382-9402. [CrossRef] [PubMed]

62. 2012 Edition of the Drinking Waters Standards and Health Advisories; EPA 822-S-12-001; Office of Water, US Environmental Protection Agency: Washington, DC, USA, 2012.

63. Håkanson, L. An ecological risk index for aquatic pollution control. A sedimentological approach. Water Res. 1980, 14, 975-1001. [CrossRef]

64. Risk Assessment Guidance for Superfund, Human Health Evaluation Manual, Part A, Interim Final; Office of Emergency and Remedial Response, US Environmental Protection Agency: Washington, DC, USA, 1989; Volume 1.

65. Dermal Exposure Assessment: A Summary of EPA Approaches; EPA/600/R-07/040F; National Center for Environmental Assessment, Office of Research and Development, US Environmental Protection Agency: Washington, DC, USA, 2007. 
66. Risk Assessment Guidance for Superfund Volume I: Human Health Evaluation Manual, Part F, Supplemental Guidance for Inhalation Risk Assessment), Final; OSWER Directive 9285, 7-82, EPA-540-R-070-002; Office of Superfund Remediation and Technology Innovation, US Environmental Protection Agency: Washington, DC, USA, 2009.

67. Risk Assessment Guidance for Superfund (RAGS), Volume I: Human Health Evaluation Manual, Part E, Supplemental Guidance for Dermal Risk Assessment, Final; Office of Solid Waste and Emergency Management, Office of Superfund Remediation and Technology Innovation, US Environmental Protection Agency: Washington, DC, USA, 2004.

68. Role of the Baseline Risk Assessment in Superfund Remedy Selection Decisions; OSWER Directive 9355.0-30; Office of Solid Waste and Emergency Response, US Environmental Protection Agency: Washington, DC, USA, 1991.

69. Soller, J.A.; Schoen, M.E.; Bartrand, T.; Ravenscroft, J.E.; Ashbolt, N.J. Estimated human health risks from exposure to recreational waters impacted by human and non-human sources of faecal contamination. Water Res. 2010, 44, 4674-4691. [CrossRef] [PubMed]

70. Schets, F.M.; Schijven, J.F.; de Roda Husman, A.M. Exposure assessment for swimmers in bathing waters and swimming pools. Water Res. 2011, 45, 2392-2400. [CrossRef]

71. Harder, R.; Heimersson, S.; Svanström, M.; Peters, G.M. Including pathogen risk in life cycle assessment of wastewater management. 1. Estimating the burden of disease associated with pathogens. Environ. Sci. Technol. 2014, 48, 9438-9445. [CrossRef] [PubMed]

72. Bastos, R.; Bisson, S.; Brooks, T.; Calderon, E.; Callan, P.; Cunliffe, D.; Deere, D.; de Roda Husman, A.M.; Endo, T.; Giddings, M.; et al. Quantitative Microbial Risk Assessment. Application for Water Safety Management; World Health Organization: Geneva, Switzerland, 2016.

73. Guidelines for Drinking-Water Quality: Fourth Edition Incorporating the First Addendum; World Health Organization: Geneva, Switzerland, 2017.

74. Regulation of the Minister of Health of 7 December 2017, Regarding the Quality of Water Designed for Human Consumption; Item 2294; Dz.U.: Warszawa, Poland, 2017.

75. Regulation of the Minister of Maritime Economy and Inland Water Navigation of 29 August 2019, Regarding the Requirements for the Surface Water, Used in Water Supply Systems Designed for the Population, to Comply with; Item 1747; Dz.U.: Warszawa, Poland, 2019.

76. Regulation of the Minister of Maritime Economy and Inland Water Navigation of 12 July 2019, Regarding the Substances Particularly Hazardous for the Water Environment and the Conditions that Must be Fulfilled when Introducing Waste to Waters or Soil, as well as when Dumping Roof Runoff or Thawing Water to Waters or Water Systems; Item 1311; Dz.U.: Warszawa, Poland, 2019.

77. Molybdenum in Drinking-Water. Background Document for Development of WHO Guidelines for Drinking-Water Quality; World Health Organization: Geneva, Switzerland, 2003.

78. Chief Inspectorate of Environmental Protection in Poland. Available online: http://powietrze.gios.gov.pl/pjp/ maps/chemistry/stations (accessed on 14 July 2020).

79. Grzyb, J.; Frączek, K. Research on bacterial aerosol spreading in Cracow. Nauka Przyr. Technol. 2010,4 , 79. (In Polish)

80. Bragoszewska, E.; Pastuszka, J.S. Influence of meteorological factors on the level and characteristics of culturable bacteria in the air in Gliwice, Upper Silesia (Poland). Aerobiologia 2018, 34, 241-255. [CrossRef]

81. Evans, C.A.; Coombes, P.J.; Dunstan, R.H. Wind, rain and bacteria: The effect of weather on the microbial composition of roof-harvested roof runoff. Water Resour. 2006, 40, 37-44. [CrossRef]

82. Evans, C.A.; Coombes, P.J.; Dunstan, R.H.; Harrison, T. Identifying the major influences on the microbial composition of roof harvested roof runoff and the implications for water quality. Water Sci. Technol. 2007, 55, 247-253. [CrossRef]

83. Sazakli, E.; Alexopoulos, A.; Leotsinidis, M. Roof runoff harvesting, quality assessment and utilization in Kefalonia Island, Greece. Water Res. 2007, 41, 2039-2047. [CrossRef] [PubMed]

84. Fewtrell, L.; Kay, D. Microbial quality of roof runoff supplies in developed countries: A review. Urban Water J. 2007, 4, 253-260. [CrossRef]

85. O’Hogain, S.; McCarton, L.; McIntyre, N.; Pender, J.; Reid, A. Physicochemical and microbiological quality of water from a pilot domestic roof runoff harvesting facility in Ireland. Water Environ. J. 2011, 25, 489-494. [CrossRef] 
86. Dobrowsky, P.H.; De Kwaadsteniet, M.; Cloete, T.E.; Khan, W. Distribution of Indigenous Bacterial Pathogens and Potential Pathogens Associated with Roof-Harvested Roof runoff. Appl. Environ. Microbiol. 2014, 80, 2307-2316. [CrossRef]

87. Schleibinger, H.; Keller, R.; Rüden, H. Indoor Air Pollution by Microorganisms and Their Metabolites. In The Handbook of Environmental Chemistry; Plushke, P., Ed.; Springer: Berlin, Germany, 2004; Volume 4, pp. 149-177. [CrossRef]

88. Womiloju, T.O.; Miller, J.D.; Mayer, P.M.; Brook, J.R. Methods to determine the biological composition of particulate matter collected from outdoor air. Atmos. Environ. 2003, 37, 4335-4344. [CrossRef]

89. Bugajny, A.; Knopkiewicz, M.; Piotraszewska-Pająk, A.; Sekulska-Stryjakowska, M.; Stach, A.; Filipiak, M. On the Microbiological Quality of the Outdoor Air in Poznań, Poland. Pol. J. Environ. Stud. 2005, 14, $287-293$.

90. Fröhlich-Nowoisky, J.; Pickersgill, D.A.; Després, V.R.; Pöschl, U. High diversity of fungi in air particulate matter. Proc. Natl. Acad. Sci. USA 2009, 106, 12814-12819. [CrossRef]

91. Hjemroos, M. Relationship between airborne fungal spore presence and weather variables: Cladosporium and Alternaria. Grana 1993, 32, 40-47. [CrossRef]

92. Grinn-Gofroń, A.; Bosiacka, B. Effects of meteorological factors on the composition of selected fungal spores in the air. Aerobiologia 2015, 31, 63-72. [CrossRef]

93. Guidelines for Drinking-Water Quality, 4th ed.; World Health Organization: Geneva, Switzerland, 2011.

94. Pepper, I.L.; Gerba, P.C. Aeromicrobiology. In Environmental Microbiology, 3rd ed.; Pepper, I.L., Gerba, P.C., Gentry, T.J., Eds.; Academic Press: Cambridge, MA, USA, 2015; pp. 89-110. [CrossRef]

95. Haas, D.; Galler, H.; Luxner, J.; Zarfel, G.; Buzina, W.; Friedl, H.; Marth, E.; Habib, J.; Reinthale, F.F. The concentrations of culturable microorganisms in relation to particulate matter in urban air. Atmos. Environ. 2013, 65, 215-222. [CrossRef]

96. Resolution No. XXXII/452/17 of the Regional Assembly of the Małopolska Region of 23 January 2017 on the Introduction in the Area of the Matopolska Region of Restrictions and Prohibitions on the Operation of Installations in which Fuel is Burned; Regional Assembly of the Małopolska Region: Kraków, Poland, 2017. (In Polish)

97. Denby, B.R.; Ketzel, M.; Ellermann, T.; Stojiljkovic, A.; Kupiainen, K.; Niemi, J.V.; Norman, M.; Johansson, C.; Gustafsson, M.; Blomqvist, G.; et al. Road salt emissions: A comparison of measurements and modelling using the NORTRIP road dust emission model. Atmos. Environ. 2016, 141, 508-522. [CrossRef]

98. Kostka, A.; Strzebońska, M.; Sobczyk, M.; Zakrzewska, M.; Bochenek, A. The effect of de-icing roads with salt on the environment in Kraków, Poland. Geology Geophys. Environ. 2019, 45, 195-205. [CrossRef]

99. Jain, C.D.; Madhavan, B.L.; Ratnam, M.V. Source apportionment of roof runoff chemical composition to investigate the transport of lower atmospheric pollutants to the UTLS region. Environ. Pollut. 2019, 248, 166-174. [CrossRef]

100. Szpakowska, B.; Świerk, D.; Gołdyn, R.; Barałkiewicz, D. Contents of $\mathrm{Cu}, \mathrm{Zn}, \mathrm{Cd}, \mathrm{Pb}$ and Fe in roof runoff effluents discharged to surface waters in the city of Poznań. J. Elem. 2014, 3, 779-794. [CrossRef]

101. Misra, A.K. Roof runoff Harvesting and Artificial Recharge of Groundwater. In Groundwater Development and Management; Sikdar, P., Ed.; Springer: Cham, Switzerland, 2019; pp. 421-439. [CrossRef]

102. Tran, S.H.; Dang, H.T.T.; Dao, D.A.; Nguyen, V.-A.; Nguyen, L.T.; Nguyen, V.-A.; Han, M. On-site roof runoff harvesting and treatment for drinking water supply: Assessment of cost and technical issues. Environ. Sci. Pollut. Res. 2020. [CrossRef]

103. Imarhiagbe, E.E.; Osarenotor, O. Health risk and quality assessment of non-roof-harvested roof runoff from an oil-producing community in Nigeria. Environ. Monit. Assess. 2020, 192, 169. [CrossRef]

104. Seeman, M.; Day, S.D.; Garvin, M.; Ramakrishnan, N.; Pearce, A. Optimal sizing of roof runoff harvesting systems for domestic water usages: A systematic literature review. Resour. Conserv. Recy. 2020, 6, 100033. [CrossRef]

105. Uba, B.N.; Aghogho, O. Roof runoff quality from different roof catchments in the Port Harcourt district, Rivers State, Nigeria. J. Water Supply Res. Technol. 2000, 49, 281-288. [CrossRef]

106. Daoud, A.K.; Swaileh, K.M.; Hussein, R.M.; Matani, M. Quality assessment of roof-harvested roof runoff in the West Bank, Palestinian Authority. J. Water Health 2011, 9, 525-533. [CrossRef]

107. PN-89/Z-04111/02. Polish Standard. Air Purity Protection-Microbiological Studies-Determination of the Numbers of Bacteria in the Atmospheric Air (Imission) when Collecting Samples by the Aspiration and Sedimentation Methods; Polski Komitet Normalizacyjny: Warszawa, Poland. (In Polish) 
108. PN-89/Z-04111/03. Polish Standard. Air Purity Protection-Microbiological Studies-Determination of the Numbers of Fungi in the Atmospheric Air (Imission) when Collecting Samples by the Aspiration and Sedimentation Methods); Polski Komitet Normalizacyjny: Warszawa, Poland. (In Polish)

109. Gołofit-Szymczak, M.; Górny, R.L. Bacterial and Fungal Aerosols in Air-Conditioned Office Buildings in Warsaw, Poland-The Winter Season. Int. J. Occup. Saf. Ergon. 2010, 16, 465-476. [CrossRef]

110. Douwes, J.; Thorne, P.; Pearce, N.; Heederik, D. Bioaerosol Health Effects and Exposure Assessment: Progress and Prospects. Ann. Occup. Hyg. 2003, 47, 187-200. [CrossRef] [PubMed]

Publisher's Note: MDPI stays neutral with regard to jurisdictional claims in published maps and institutional affiliations.

(C) 2020 by the authors. Licensee MDPI, Basel, Switzerland. This article is an open access article distributed under the terms and conditions of the Creative Commons Attribution (CC BY) license (http://creativecommons.org/licenses/by/4.0/). 